
\title{
Author Correction: The influence of latitude, geographic distance, and habitat discontinuities on genetic variation in a high latitude montane species
}

\author{
J. A. Hindley ${ }^{1}$, B. A. Graham $\mathbb{1}^{1}$, P. C. Pulgarin-R. $\mathbb{1}^{2,3}$ \& T. M. Burg ${ }^{1}$ \\ Correction to: Scientific Reports https://doi.org/10.1038/s41598-018-29982-7, published online 07 August 2018 \\ In this Article, the Data availability section was omitted from the Additional Information section:
}

\section{Data Availability}

All sequences used for the mtDNA analyses in this project have been deposited in genbank accession numbers MK055563 - MK055752.

(c) (i) Open Access This article is licensed under a Creative Commons Attribution 4.0 International cc) License, which permits use, sharing, adaptation, distribution and reproduction in any medium or format, as long as you give appropriate credit to the original author(s) and the source, provide a link to the Creative Commons license, and indicate if changes were made. The images or other third party material in this article are included in the article's Creative Commons license, unless indicated otherwise in a credit line to the material. If material is not included in the article's Creative Commons license and your intended use is not permitted by statutory regulation or exceeds the permitted use, you will need to obtain permission directly from the copyright holder. To view a copy of this license, visit http://creativecommons.org/licenses/by/4.0/.

(C) The Author(s) 2018

${ }^{1}$ Department of Biological Sciences, University of Lethbridge, 4401 University Dr. W, Lethbridge, AB, T1K 3M4, Canada. ${ }^{2}$ Laboratorio de Biología Evolutiva de Vertebrados, Departamento de Ciencias Biológicas, Universidad de Los Andes, Bogota, Colombia. ${ }^{3}$ Facultad de Ciencias y Biotecnología, Universidad CES, Medellin, Colombia. Correspondence and requests for materials should be addressed to B.A.G. (email: b.graham001@gmail.com) 